


\title{
EFFECT OF LEVEL OF CONCENTRATE FEEDING LEVEL ON EFFICIENCY OF EATING BEHAVIOUR ON ONGOLE CROSSBRED CATTLE
}

\author{
S. Dartosukarno, F. Iskandar and A. Purnomoadi \\ Faculty of Animal Agriculture, Diponegoro University, \\ Tembalang Campus, Semarang 50275 - Indonesia \\ Corresponding E-mail: agung194@yahoo.com
}

Received January 08, 2012; Accepted February 24, 2012

\begin{abstract}
ABSTRAK
Delapan ekor sapi Peranakan Ongole (PO) jantan dengan bobot badan (BB) awal $297 \pm 26 \mathrm{~kg}$ (CV $=8,75 \%$ ) yang diberi pakan jerami padi yang diurinasi (JU) ad libitum digunakan dalam penelitian untuk mengetahui pengaruh level konsentrat terhadap efisiensi tingkah laku makan sapi. Sapi dibagi menjadi dua kelompok masing masing berisi empat ekor untuk dua perlakuan berupa pemberian konsentrat (K) sebesar 1\% BB dan 2\% BB masing masing untuk kelompok JUK1 dan JUK2. Pakan konsentrat terdiri dari ampas bir dan dedak padi dengan kandungan protein kasar $14 \%$. Pengamatan tingkah laku makan diukur selama 3x24 jam dan dilakukan dua kali pada minggu ke 2 dan ke 6 penelitian. Data yang diperoleh dianalisa dengan uji t. Hasil penelitian menunjukkan bahwa level konsentrat berpengaruh terhadap konsumsi $\mathrm{BK}$ jerami urinasi $(\mathrm{P}<0,01)$ dan $\mathrm{PBBH}(\mathrm{P}<0,05)$ meskipun tidak berbeda nyata $(\mathrm{P}>0,05)$ pada konsumsi BK total, waktu makan $(196,5$ vs 221,5 menit/hari); waktu ruminasi (351,0 vs 449,4 menit/hari), efisiensi waktu makan (37,21 vs 37,67 gBK/menit), dan efisiensi waktu ruminasi (21,43 vs $18,50 \mathrm{gBK} /$ menit). Penelitian ini menyimpulkan bahwa pemberian konsentrat pada level $2 \% \mathrm{BB}$ tidak merubah efisiensi waktu makan dan ruminasi dibanding dengan $1 \% \mathrm{BB}$, meskipun mampu memperbaiki PBBH.
\end{abstract}

Kata kunci : tingkah laku makan, sapi PO, level konsentrat.

\begin{abstract}
Eight bulls of Ongole Crossbred (OC) cattle with initial body weight (BW) of $297 \pm 26 \mathrm{~kg}$ (CV = $8.75 \%$ ) fed rice straw treated with urine (RU) (ad libitum) were divided into two groups (each four heads) to determine the effect of concentrate feeding level on efficiency of eating behavior. The cattle was given concentrate feeding composed of beer cake and rice bran to make $14 \%$ crude protein at $1 \%$ and at $2 \%$ BW for RUC1 and RUC2 group, respectively. Eating behavior was measured for $3 \times 24$ hours and was performed twice at weeks 2 and 6 of the study. Data obtained were analyzed by t-test. The results showed that the level of concentrate feeding affected the intake of urinated rice straw $(\mathrm{P}<0.01)$ and daily BWGain $(\mathrm{P}<0.05)$, but the effect was not found $(\mathrm{P}>0.05)$ on DMI, length time for eating (196.5 vs. $221.5 \mathrm{~min} / \mathrm{d})$, length time for rumination (351.0 vs. $449.4 \mathrm{~min} / \mathrm{d})$, efficiency of eating time (37.21 vs. $37.67 \mathrm{gDM} / \mathrm{min}$ ) and efficiency rumination time (21.43 vs. $18.50 \mathrm{gDM} / \mathrm{min})$. This research showed that concentrate feeding at $2 \% \mathrm{BW}$ did not alter the efficiency of eating time and rumination compared to $1 \% \mathrm{BW}$, although able to improve BWG of OC cattle.
\end{abstract}

Keywords: eating behavior, OC cattle, level of concentrate.

\section{INTRODUCTION}

Feeding is one of important factors determine the performance of beef production, since the feed given is a source of nutrients for animal to produce a product, such as power, meat or milk. In farm operational management, feed efficiency is also considered to obtain either from the economical side or from zootechnical side.
The influence of feed on the efficiency is usually evaluated with nutritional parameters, such as chemical composition, digestibility, (Owens et al., 2010) or feed conversion rate (Comerford et al., 1991). However, evaluation on the animal behavior in responding the feed given is not widely observed (Bingham et al., 2009). The animal's acceptability to the feeds offered is very important factor correlated to the length time 
needed for adapting to the new feeding management for newly coming animal.

The animal's acceptability to the feeds can be measured by observing the time required to consume a certain amount of feed offered. On the other hand, the time to consume feed is correlated with chewing activity and rumination which is attempted by animal to reduce the particle size of feed to pass the rumen to be digested in the lower digestive tract (Fraser, 1974; Susenbeth et al., 1998). The time spend for eating can reach 13-17 hours per day (Bosch et al., 1992;. Brouk and Belyea, 1993), and may use $25 \%$ of the energy metabolized from feed (Vermorel and Mormede, 1991) and affects on the efficiency of feed utilization (Ørskov and MacLeod, 1990).

Increasing production is a condition required for economical benefit, usually is done by giving better feed quality. Good quality of feed is characterized by high digestibility in the rumen so that the feed also has a higher passage rate and higher feed consumption as well. The high feed consumption has a consequence on high allocation of time to eat as well as spend a higher energy for eating activities. With regard to the above explanation, the research on efficiency of eating behavior on different feeding qualities, especially in the case of addition of of concentrate feeding at different levels needs to be done.

\section{MATERIALS AND METHODS}

\section{Animal used}

The material used in this study was eight Ongole Crossbred (OC) bulls with initial body weight of $297 \pm 26 \mathrm{~kg}(\mathrm{CV}=8.75 \%)$ with averaged age two years old. The cattle were divided into two groups, each containing four heads for the two treatments. The cattle were divided into two groups, each contained four heads for the two treatments.

\section{Feeding treatments}

The feedstuffs used in this study was rice straw treated with urine (RU) and concentrate feeding. The RU was prepared by ensiled rice straw with urine in the ratio 1 liter of urine for 1 $\mathrm{kg}$ of rice straw (air dry weight; about 15\% dry matter), in sealed polythene bags for two weeks. The urine used for rice straw treatment was collected from dairy cattle. However, the concentrate feeding was composed of $70 \%$ rice bran and $30 \%$ beer cake to make crude protein content of $14 \%$. The first feeding treatment was RU (ad libitum) and concentrate feeding given at $1 \%$ of body weight (BW) (RUC1), whereas the second treatment was RU (ad libitum) and concentrate feeding given at $2 \% \mathrm{BW}$ (RUC2). Nutrient content of feed is shown in Table 1. Concentrate feeding was given twice daily at 0800 and 1500, while RU was given ad libitum started at $2 \mathrm{~h}$ post concentrate feeding in morning. Water was given ad libitum.

\section{Parameters measurements and data analysis}

Observation of eating behavior was measured for $3 \times 24$ hours and was performed twice with 4 weeks interval. Parameters measured for eating behavior was length time for eating and rumination $(\mathrm{min} / \mathrm{d})$, as well as efficiency of time for eating and rumination $(\mathrm{gDM} / \mathrm{min})$. The eating and rumination activity was measured manually by observing the dominant activity for each 5 minutes. Eating activity is characterized by cattle taking the feed from the feed bunk and put into the mouth, whereas rumination activity is characterized by jaw movements that are not preceded by taking feed. Another parameter observed was the dry matter intake (DMI). Efficiency of eating and rumination time was calculated by dividing daily DMI with eating or rumination time and expressed as $\mathrm{gDM} / \mathrm{min}$. Daily eating behavior is also expressed in day and night during $24 \mathrm{~h}$. Data obtained were analyzed by t-test (Steel and Torrie, 1981).

\section{RESULTS AND DISCUSSION}

Daily dry matter intake (DMI) and the daily allocation of time eating and rumination at the time of measurement are shown in Table 2. Total feed consumption in both feeding treatments of RUC1 and RUC2 were not significantly different (P>0.05), being 7.52 and $8.33 \mathrm{~kg} / \mathrm{d}$, respectively. This condition was interesting because the DMI from concentrate feeding in RUC1 was lower than in RUC2 $(\mathrm{P}<0.05)$ in accordance with the treatment applied, but the DMI from RU in RUC1 was higher $(\mathrm{P}<0.05)$ than in RUC2. The contrast conditions between the DMI from concentrates feeding and RU which gives the similar total DMI is expected due to the similar capacity of the rumen of the cattle used in this study. The similar weight and age of cattle in this study may give a similar rumen capacity.

The daily eating time of RUC1 and RUC2 were not different $(\mathrm{P}>0.05)$, being 196 and 221 
Table 1. Nutrients Compositions in Feedstuffs Used in the Study (100\%DM base)

\begin{tabular}{lccccc}
\hline Feedstuff & Ash & EE & CP & CF & NFE \\
\hline Rice straw urinated & 36.16 & 1.48 & 11.02 & 27.74 & 23.60 \\
Concentrate & 13.60 & 1.70 & 13.92 & 15.09 & 55.69 \\
\hline
\end{tabular}

EE: Extract Ether, CP: Crude Protein, CF: Crude Fiber, NFE: Nitrogen Free Exctract

Table 2. Dry Matter Intake, Eating Time, Rumination Time, and Eating and Rumination Efficiency during Eating Behavior Observation

\begin{tabular}{|c|c|c|c|}
\hline & RUC1 & RUC2 & Signif. \\
\hline & \multicolumn{3}{|c|}{ f..................kg DM/d .................... } \\
\hline Dry matter intake & 7.52 & 8.33 & ns \\
\hline Rice straw urinated & 4.25 & 2.52 & $*$ \\
\hline \multirow[t]{2}{*}{ Concentrate } & 3.27 & 5.81 & $*$ \\
\hline & \multicolumn{3}{|c|}{ 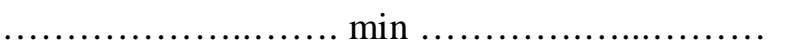 } \\
\hline Eating time & 196.46 & 221.46 & $\mathrm{~ns}$ \\
\hline Day & 141.88 & 179.38 & ns \\
\hline \multirow[t]{2}{*}{ Night } & 54.58 & 42.08 & ns \\
\hline & \multicolumn{3}{|c|}{ 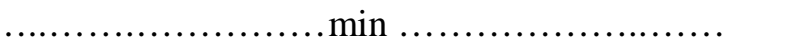 } \\
\hline Rumination time & 351.04 & 449.38 & ns \\
\hline Day & 95.83 & 146.04 & ns \\
\hline \multirow[t]{2}{*}{ Night } & 255.20 & 303.33 & $\mathrm{~ns}$ \\
\hline & \multicolumn{3}{|c|}{$\ldots \ldots \ldots \ldots \ldots \ldots \ldots . \mathrm{gDM} / \min . \ldots \ldots \ldots \ldots \ldots \ldots \ldots$} \\
\hline Eating time efficiency & 37.21 & 37.67 & ns \\
\hline Rumination time efficiency & 21.43 & 18.50 & ns \\
\hline
\end{tabular}

ns: Not significant $(\mathrm{P}>0.05) ; *$ : Significant $(\mathrm{P}<0.05)$

minutes, respectively which was divided in the afternoon period (72 vs. $81 \%$ ) and night (27 vs. $19 \%$ ), which the proportion were also not different $(\mathrm{P}>0.05)$. The daily eating and ruminating time at the day and night is illustrated in Figure 1. The dominant proportion of time for eating during the day may be pointed to feeding was given during the day. The pattern in rumination time was slightly different from the pattern of eating times, although statistically was not different. Proportion of rumination time during the day and night on RUC1 and RUC2 were in the contrary to the proportion of time for eating. These facts indicated that rumination tended to occur at night, confirmed to research of Rotger et al. (2006), or may also be due to reducing lighting sufficient for activity (Tanida $e t$ al., 1984).

Eating time patterns descriptively showed that RUC1 was 25 minutes shorter than RUC2, while in rumination time, the time for RUC1 was almost 100 minutes lower than for RUC2. There are several reasons that could explain this phenomenon. The first, the eating activity is correlated linearly with the amount of feed consumed, because eating activity is calculated based on the activity of taking the feed from the feed bunk to the mouth. This reason can also explain the pattern of time for rumination. The difference in rumination time was considered to be related to the degree of breakable of feed in the rumen. The total rumination time (or in day and night time) on RUC2 was longer than the RUC1, whereas the consumption of rice straw (which is known as hardly to be broken material) in RUC2 was less than RUC1. Under these conditions, theoretically rumination time in RUC2 was shorter than the RUC1. This discrepancy in 

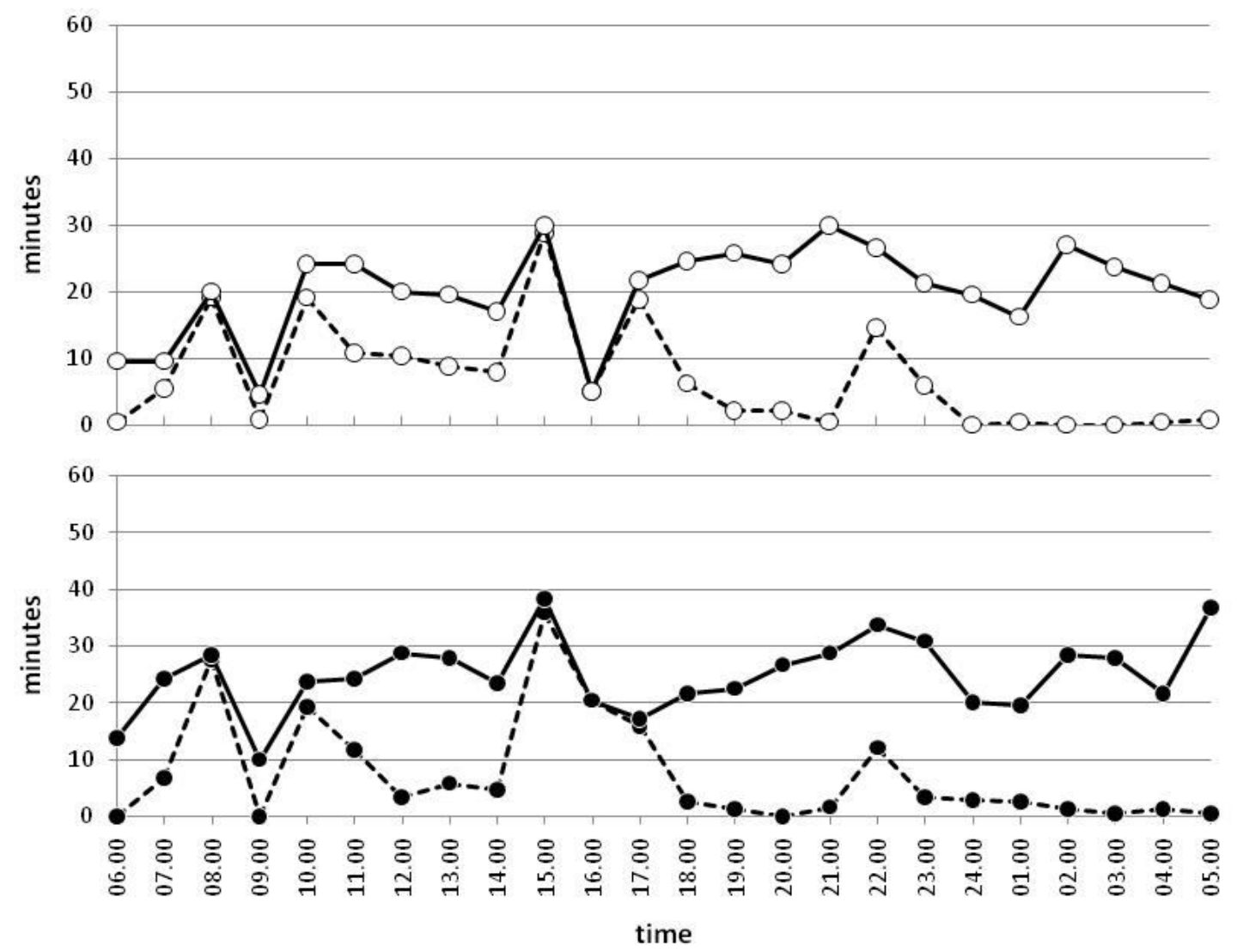

Figure 1. Allocation Time for Activity of Eating (dashed line) and Rumination (solid line) in Minutes for Each Hour during 24 Hours Observation. The above was for RUC1 while the below was for RUC2.

rumination time lead to the consideration that factors determining rumination activity is much more related to total amount of feed ingested rather than the quality or composition of the diet, i.e. ratio concentrate feeding and roughage.

The data in Table 2 showed that both time of rumination on the day and night, each increased for about 50 minutes. The efficiency of eating and rumination time between RUC1 and RUC2 in Table 2 was also not significantly different $(\mathrm{P}>0.05)$. Efficiency of eating and rumination in this study was termed as the amount of feed that can be eaten (to be swallowed) or can be ruminated (to be passed through the rumen) and expressed as $\mathrm{gDM} / \mathrm{min}$. Efficiency of eating and rumination time for RUC1 (37.21 and 21.43 $\mathrm{gDM} / \mathrm{min})$ and RUC2 (37.67 and 18.50 $\mathrm{gDM} / \mathrm{min}$ ) showed similarity $(\mathrm{P}>0.05)$. These data suggested that the ability of cattle to break down feed particles that can be swallowed in one minute, approximately two times higher (or doubled) than the ability of cattle to break down feed particles to passed out of the rumen into the further digestive tract. Despite the efficiency of eating and rumination time was not significantly different $(\mathrm{P}>0.05)$, numerically, the efficiency of rumination time to break down feed particles on RUC1 was $0.3 \mathrm{gDM} / \mathrm{min}$ better than RUC2. It becomes hard to be explained that in RUC2 the proportion of concentrates in feed was higher than that in RUC1. If concentrate feeding was intended to provide nutrition needed for improving rumen microbial growth and was then able to support digestion of fibrous feed (rice straw urinated), this study showed that such mechanisms did not occur properly. Inability to improve efficiency of eating and rumination time was allegedly as an influence of rice straw (even though already being urinated) as fibrous feed used in this study. Rice straw is known as a material rich in fiber, lignin and low digestibility, or in other words, urination process failed to improve the digestibility of rice straw. Thus, improving the efficiency of eating and rumination activity due to the provision of 
concentrate at levels of 1 and $2 \%$ body weight did not occur.

\section{CONCLUSION}

Provision of concentrate feeding at a level up to $2 \%$ of body weight was not able to provide the efficiency of eating and rumination activity. Inability to deliver improved efficiency of eating and rumination activity allegedly due to the influence of rice straw that rich in fiber and lignin, and that cannot be improved by urination process.

\section{ACKNOWLEDGMENTS}

The authors thank to the JEFRIN research team and Aries R. Setyawan for assistance during the data collection period.

\section{REFERENCES}

Bingham, G. M., T. H. Friend, P. A. Lancaster and G. E. Carstens. 2009. Relationship between feeding behavior and residual feed intake in growing Brangus heifers. J. Anim Sci. 87:2685-2689.

Bosch, M. W., S.C.W. Lammers-Wienhoven, G. A. Bangma, H. Boer, and P.W.M. van Adrichem. 1992. Influence of stage of maturity of grass silages on digestion processes in dairy cows. 2. Rumen contents, passage rates, distribution of rumen and faecal particles and mastication activity. Livest. Prod. Sci. 32:265-281.

Brouk, M., and R. Belyea. 1993. Chewing activity and digestive responses of cows fed alfalfa forages. J. Dairy Sci. 76:175-182.

Comerford, J. W., J. B. Cooper, L. L. Benyshek, and J. K. Bertrand. 1991. Evaluation of feed conversion in steers from a diallel of Simmental, Limousin, Polled Hereford, and Brahman beef cattle. J. Anim. Sci. 69:27702778.

Fraser, A.F. 1974. Farm Animal Behaviour, An Introductory Textbook on the Study of Behaviour as Applied to Horse, Cattle, Sheep, and Pig. Bailliere Tindal, London.

Ørskov, E. R., and N. A. MacLeod. 1990. Dietaryinduced thermogenesis and feed evaluation in ruminants. Proc. Nutr. Soc. 49:227-237.

Owens, F. N., D. A. Sapienza and A. T. Hassen. 2010. Effect of nutrient composition of feeds on digestibility of organic matter by cattle: A review. J. Anim Sci. 88:E151-E169. doi:10.2527/jas.2009-2559

Rotger, A., A. Ferret, X. Menteca, J.L. Ruiz de la Torre and S. Calsamiglia. 2006. Effects of dietaery nonstructural carbohydrates and protein sources on feeding behavior of tethered heifers fed high-concentrate diets. J. Anim. Sci. 84:1197-1204.

Steel, R.G.D. and J.H. Torrie. 1981. Principles and Procedures of Statistics. McGraw-Hill Company Inc., New York.

Susenbeth, A., R. Mayer, B. Koehler, and O. Neumann. 1998. Energy Requirement for Eating in Cattle. J. Anim. Sci. 76:2701-2705.

Tanida, H., L. V. Swanson, and W. D. Hohenboken. 1984. Effect of artificial photoperiod on eating behavior and other behavioral observations of dairy cows. J. Dairy Sci. 67:585-591.

Vermorel, M., and P. Mormede. 1991. Energy cost of eating in ponies. In: C. Wenk, and M. Boessinger (Ed.) Energy Metabolism of Farm Animals. EAAP Publ. No. 58. p 437. Zurich, Switzerland. 